\title{
An Empirical Comparison of the Corporate Financing Behavior: The Case Study of the Major US and Japanese Firms in the Electrical-related Industries
}

\author{
Chikashi Tsuji \\ Faculty of Economics, Chuo University \\ 742-1 Higashinakano Hachioji-shi, Tokyo 192-0393, Japan \\ E-mail: mail_sec_low@minos.ocn.ne.jp
}

Received: September 22, 2014 Accepted: October 17, 2014 Published: November 30, 2014

doi:10.5296/ifb.v1i2.6696 URL: http://dx.doi.org/10.5296/ifb.v1i2.6696

\begin{abstract}
This paper explores the corporate financing behavior of four large electrical-related industry firms in the US and Japan. The interesting findings from our case study are as follows. (1) First, as for Apple Inc. (Apple), our results can be interpreted that the firm raises funds by equity when its market value is high. Further, our empirical results also show that the Apple is considered to finance the funds for R\&D and tangible assets mainly by debt rather than equity. (2) Second, regarding International Business Machines Corporation (IBM), the firm is considered to finance the funds for R\&D mainly by equity rather than debt; however, the debt ratio of this firm is generally high. (3) Third, as for Panasonic Corporation (Panasonic), the firm is considered to finance the funds for property, plant, and equipment mainly by debt rather than equity, and the rapid increase of its debt ratio is seen in the recent period. (4) Finally, as to Sony Corporation (Sony), the company is considered to finance the funds for property, plant, and equipment and $R \& D$ expenses mainly by equity rather than debt whilst its debt ratio is also generally high.
\end{abstract}

Keywords: Capital structure, Debt financing, Electrical industry, Equity financing, Market timing 


\section{Introduction}

The US electrical industry firms such as Apple Inc. (Apple) demonstrate the continuous growth both in corporate profits and firm values. On the other hand, the Japanese electrical industry firms such as Panasonic Corporation (Panasonic) and Sony Corporation (Sony) have been suffering from the economic slump in Japan. Based on the differences, how did the US and Japanese electrical-related industry firms raise their funds? Further, how did the capital structures of the well-known US and Japanese electrical-related industry firms change?

In order to clarify these issues more in detail, this paper employs the case study that shall be quite effective in our context. Needless to say, corporate capital structure is one of the most important topics in the field of corporate finance as the important studies of Myers and Majluf (1984), Baker and Wurgler (2002), Frank and Goyal (2009) and many others demonstrate. We also point out that the case studies related to corporate capital structure would not be plenty in the existing literature.

Based on the above points, in this paper, we aim to clarify the differences of debt financing and equity financing behavior of the specific US and Japanese electrical-related industry firms: Apple, International Business Machines Corporation (IBM), Panasonic, and Sony. Our empirical examinations reveal many interesting characteristics of the four firms as to corporate capital structure related issues as we describe in the later sections. The above derivation as to the US and Japanese representative electrical-related industry firms is the contribution of this case study. Regarding the organization of this paper, Section 2 reviews the related latest studies; Section 3 explains our data and variables; Sections 4 describes our analyzing models; Section 5 explains our empirical results; Section 6 summarizes the paper.

\section{Literature Review}

This section reviews the latest related studies. First, Chung et al. (2013) analyzed the US oil industry firms and they suggested that there was no relation between capital structure policy and acquisition or failure probability in the firms. They also suggested that the firms seemed to increase leverage when their equity values are reduced by poor operating performance or when they recognize attractive growth opportunities. Yang (2013) constructed a dynamic corporate financing trade-off model with belief differences between the outside investors and insider managers. Using the model, this study suggested that the optimal leverage ratio could differ largely from that from standard trade-off models and the optimal leverage ratio depended on the differences of the opinion of outside investors and insider managers. Danis et al. (2014) suggested that the negative correlation between profitability and leverage is puzzling. They analyzed the US firms and found that the correlation between leverage and profitability was positive when firms are at or close to their optimal leverage levels.

Further, Chang et al. (2014) found that for the US firms, corporate governance significantly affected their capital structure adjustment speeds. They suggested that in both over-levered and under-levered firms with weak governance, their leverage ratios were slowly adjusted toward their target debt levels. Bonaimé et al. (2014) analyzed the US firms and suggested that the adjustments of capital structure were based on a value-increasing motive for stock 
repurchases. They also suggested that the degree of firm value creation by adjusting capital structure through a share repurchase depended on the degree of undervaluation of the firm. Vermaelen and $\mathrm{Xu}$ (2014) pointed out that when their shares are overvalued, bidders prefer to pay with stock; however, target firms tended to be reluctant to accept such overvalued payment. They found that in a sample of 2,978 acquisitions of US firms, only when the bidder can justify the financing decision in terms of such economic fundamentals as optimal capital structure, stock payment was readily accepted. Generally, there would be little case study as to capital structure.

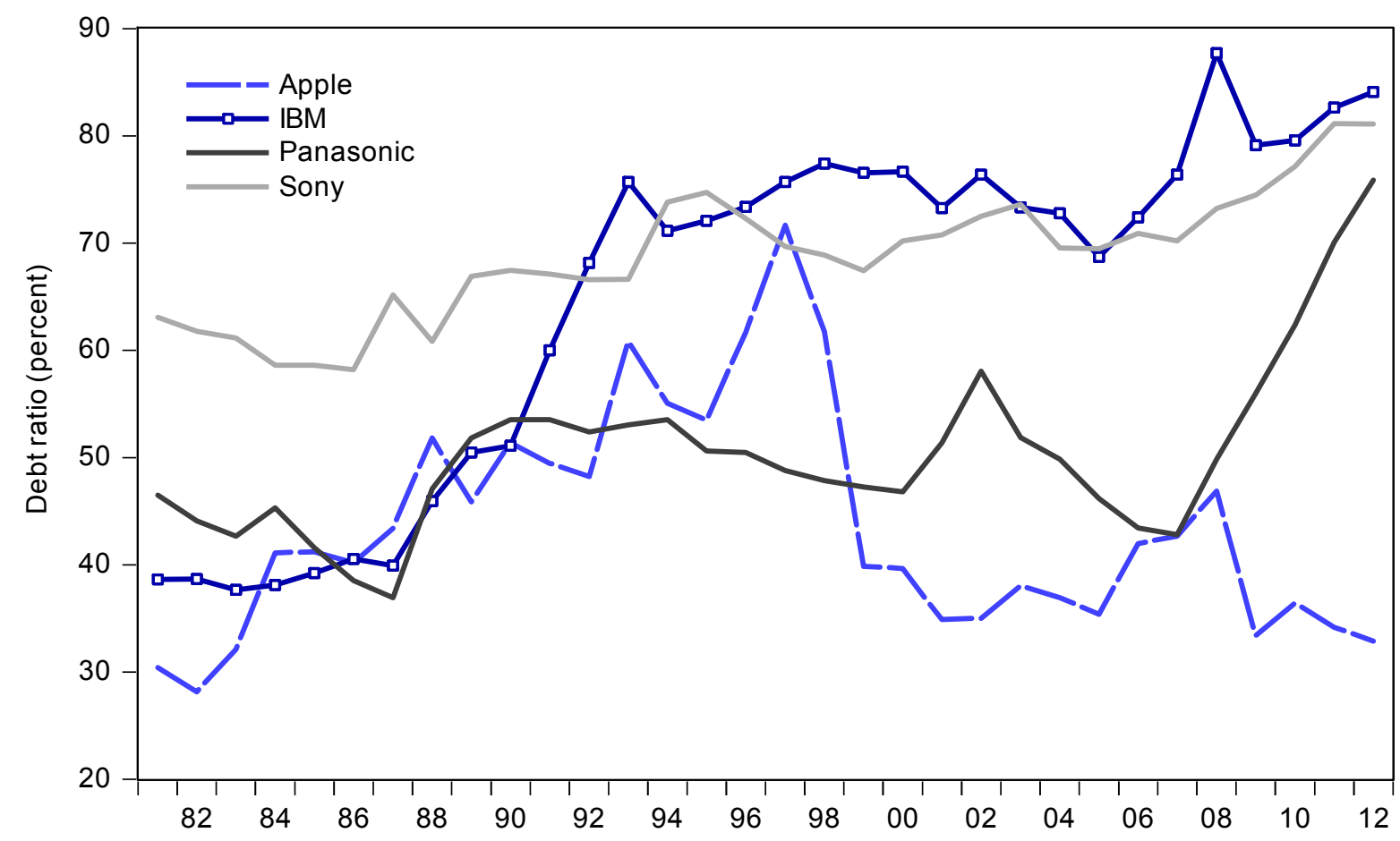

Figure 1. The Dynamics of the Debt Ratios of the Major US and Japanese Electrical-related Industry Firms: Time-series Evolution for the Period from 1981 to 2012

\section{Data}

This section explains the data and variables analyzed in this study. First, our full sample period spans the fiscal year of 1981 to 2012. We obtained all US financial and stock price related data from the Compustat data base, which is supplied by the Standard \& Poor's Financial Services LLC whilst all Japanese data are obtained from the Quick Corp. Using the data, we compute the financial ratios and market price ratios of two US electrical-related industry firms, Apple and IBM and two Japanese same industry firms, Panasonic and Sony.

Describing our financial ratio and market value variables, they are as follows: 1) DR: total debt to total asset ratio; 2) EBITDA: EBITDA to total asset ratio; 3) MB: market-to-book ratio; 4) DIV: dividend amount paid to shareholders' equity ratio. Moreover, 5) PPE denotes property, plant, and equipment to total asset ratio; 6) RD means R\&D expenses to total asset ratio; 7) SEG denotes the shareholders' equity growth rate. As above, we use and analyze the seven variables in terms of the four US and Japanese electrical-related firms in this study. 


\section{Models}

\subsection{Models for Analyzing Capital Structure Determinants}

Using the variables explained in Section 3, we conduct several regressions as to the four US and Japanese electrical-related industry firms. We implement regression analyses by employing many combinations of the variables we constructed; our full regression model using all our variables is as follows.

$$
D R_{i, t+1}=v_{i}+\xi_{i, 1} E B I T D A_{i, t}+\xi_{i, 2} M B_{i, t}+\xi_{i, 3} D I V_{i, t}+\xi_{i, 4} R D_{i, t}+\xi_{i, 5} P P E_{i, t}+\eta_{i, t+1}
$$

As explained, in the above regression (1), DR denotes the total debt to total asset ratio; EBITDA means EBITDA to total asset ratio; MB denotes the market-to-book ratio; DIV represents the dividend amount paid to shareholders' equity ratio; RD means the R\&D expenses to total asset ratio; PPE denotes property, plant, and equipment to total asset ratio.

\subsection{Models for Analyzing the Relations of Equity Financing}

In addition to the regression model for analyzing corporate debt financing, we also use the following models (2) to (4) for investigating corporate equity financing behavior.

$$
\begin{aligned}
& S E G_{i, t+1}=\mu_{i}+\psi_{i} M B_{i, t}+\omega_{i, t+1} \\
& S E G_{i, t+1}=v_{i}+\zeta_{i} R D_{i, t}+\tau_{i, t+1} \\
& S E G_{i, t+1}=\pi_{i}+\kappa_{i} P P E_{i, t}+i_{i, t+1}
\end{aligned}
$$

In models (2) to (4), SEG indicates the growth rate of shareholders' equity. Adding explanations, the model (2) is to examine the market timing hypothesis in corporate equity financing behavior; the model (3) is to analyze the linkage between R\&D expenses and corporate equity financing; model (4) is to investigate the linkage between the trends of property, plant, and equipment and corporate equity financing.

\section{Empirical Results}

\subsection{Descriptive Statistics for the Analyzing Variables}

Explaining the state of descriptive statistics of the variables for the four firms we analyze, first, as shown in Table 1, the historical average of debt ratio is the highest in Sony and the lowest in Apple. Further, IBM shows the highest historical average in EBITDA and MB, and Apple records the second highest EBITDA and MB values. As for DIV and PPE, the historical averages of IBM are the highest values; as to RD and SEG, Apple's historical averages are the highest. On the other hand, regarding the Japanese electrical-related industry firms, Panasonic and Sony, it is understood that their overall financial conditions and market values are inferior to the two US electrical-related industry firms in general. 
Table 1. Descriptive Statistics of Dependent and Independent Variables: For the Period from the Fiscal Year of 1981 to 2012

\begin{tabular}{|c|c|c|c|c|}
\hline \multicolumn{5}{|c|}{ Panel A. DR } \\
\hline & Apple & IBM & Panasonic & Sony \\
\hline Mean & 43.6111 & 64.7855 & 50.3013 & 68.8385 \\
\hline Std. Dev. & 10.5025 & 16.5494 & 8.0726 & 5.9724 \\
\hline Skewness & 0.8247 & -0.634 & 1.2687 & 0.0157 \\
\hline \multicolumn{5}{|c|}{ Panel B. EBITDA } \\
\hline & Apple & IBM & Panasonic & Sony \\
\hline Mean & 17.2776 & 19.0619 & 9.0474 & 8.1321 \\
\hline Std. Dev. & 13.0724 & 6.8746 & 3.6910 & 3.4913 \\
\hline Skewness & -0.8248 & 1.1396 & 0.9653 & 0.2133 \\
\hline \multicolumn{5}{|c|}{ Panel C. MB } \\
\hline & Apple & IBM & Panasonic & Sony \\
\hline Mean & 3.6939 & 4.7367 & 1.2654 & 1.8208 \\
\hline Std. Dev. & 2.0273 & 3.0926 & 0.3250 & 0.9802 \\
\hline Skewness & 0.9386 & 0.6251 & 0.5004 & 2.6958 \\
\hline \multicolumn{5}{|c|}{ Panel D. DIV } \\
\hline & Apple & IBM & Panasonic & Sony \\
\hline Mean & 0.8935 & 7.7645 & 0.9553 & 1.2829 \\
\hline Std. Dev. & 1.3653 & 4.6408 & 0.4438 & 0.4056 \\
\hline Skewness & 1.0618 & 1.2360 & 3.4052 & 0.5815 \\
\hline \multicolumn{5}{|c|}{ Panel E. PPE } \\
\hline & Apple & IBM & Panasonic & Sony \\
\hline Mean & 9.3485 & 24.5616 & 17.9275 & 18.6489 \\
\hline Std. Dev. & 2.3138 & 12.3977 & 4.6254 & 6.4538 \\
\hline Skewness & -0.0689 & 1.0783 & 0.8353 & -0.6848 \\
\hline \multicolumn{5}{|c|}{ Panel F. RD } \\
\hline & Apple & IBM & Panasonic & Sony \\
\hline Mean & 8.7760 & 5.5544 & 6.0419 & 5.2962 \\
\hline Std. Dev. & 4.7850 & 0.7545 & 1.3886 & 1.2850 \\
\hline Skewness & 0.4116 & 0.6585 & 0.5830 & 0.4420 \\
\hline \multicolumn{5}{|c|}{ Panel G. SEG } \\
\hline & Apple & IBM & Panasonic & Sony \\
\hline Mean & 43.8970 & 2.4022 & 4.7377 & 9.9015 \\
\hline Std. Dev. & 101.9589 & 19.7359 & 18.4304 & 15.3640 \\
\hline Skewness & 4.8140 & 0.3344 & -0.1498 & 0.1735 \\
\hline
\end{tabular}

Notes: In the table, Std. Dev. denotes the standard deviation and all descriptive statistics above are computed for our full sample period from the fiscal year of 1981 to 2012. Further, Apple means Apple Inc., IBM denotes International Business Machines Corporation, Panasonic means Panasonic Corporation, and Sony denotes Sony Corporation, respectively. 
Table 2. Results of Regressions on Debt Ratios as to the US Electrical-related Industry Firms: Determinants of Leverage for the Fiscal Year from 1981 to 2012

Panel A. Apple

\begin{tabular}{|c|c|c|c|c|c|}
\hline & Reg. 1 & Reg. 2 & Reg. 3 & Reg. 4 & Reg. 5 \\
\hline Const. & $48.4040 * * *$ & $48.0686^{* * *}$ & $40.5459 * * *$ & $31.2106^{* * *}$ & $18.7416^{* * *}$ \\
\hline EBITDA & -0.2605 & & & & \\
\hline MB & & -1.1067 & & & \\
\hline DIV & & & $4.0867 * * *$ & & \\
\hline $\mathrm{RD}$ & & & & $1.4257 * * *$ & \\
\hline PPE & & & & & $2.7005^{* * *}$ \\
\hline \multirow[t]{2}{*}{$\operatorname{Adj} . R^{2}$} & 0.0746 & 0.0143 & 0.2657 & 0.3948 & 0.3513 \\
\hline & Reg. 6 & Reg. 7 & & & Reg. 9 \\
\hline Const. & $32.5507 * * *$ & $23.7569 * * *$ & & $* * *$ & $28.8417 * * *$ \\
\hline EBITDA & & & & & $-0.4986^{* * *}$ \\
\hline MB & & & & & $1.6935 * * *$ \\
\hline DIV & 1.5313 & 1.8442 & & & $3.3062 * *$ \\
\hline $\mathrm{RD}$ & $1.1313^{* *}$ & & & & $0.6919^{*}$ \\
\hline PPE & & 1.9969 & & & 0.8900 \\
\hline $\operatorname{Adj} . R^{2}$ & 0.3979 & 0.3643 & & & 0.6265 \\
\hline
\end{tabular}

Panel B. IBM

\begin{tabular}{lllllll}
\hline & Reg. 1 & Reg. 2 & Reg. 3 & Reg. 4 & Reg. 5 & Reg. 6 \\
\hline Const. & $94.1744^{* * *}$ & $50.4455^{* * *}$ & $67.6893^{* * *}$ & $155.0506^{* * *}$ & $95.0607^{* * *}$ & $78.6775^{* * *}$ \\
EBITDA & $-1.5041^{* * *}$ & & & & & $-1.4601^{* * *}$ \\
MB & & $3.3598^{* * *}$ & & & & $3.2440^{* * *}$
\end{tabular}

DIV

$-0.2795$

$\mathrm{RD}$

$-16.0530 * * *$

PPE

\begin{tabular}{lllllll} 
Adj. $2^{2}$ & 0.4039 & 0.3400 & -0.0292 & 0.5614 & 0.8136 & 0.7438 \\
\hline & Reg. 7 & Reg. 8 & Reg. 9 & Reg. 10 & Reg. 11 & Reg. 12 \\
\hline Const. & $147.6494^{* * *}$ & $97.1414^{* * *}$ & $129.6937^{* * *}$ & $90.4798^{* * *}$ & $124.0709^{* * *}$ & $116.7160^{* * *}$ \\
EBITDA & $-0.7548^{*}$ & -0.2150 & & & & -0.3995 \\
MB & & & $1.7593^{* *}$ & 0.5758 & & 0.6535 \\
DIV & & & & & & 0.3706 \\
RD & $-12.1530^{* *}$ & & $-12.9282^{* * *}$ & & $-6.3355^{* *}$ & $-5.5446^{*}$ \\
PPE & & $-1.0983^{* * *}$ & & $-1.0992^{* * *}$ & $-0.9269^{* * *}$ & $-0.7329^{* * *}$ \\
Adj. $R^{2}$ & 0.6237 & 0.8122 & 0.6287 & 0.8144 & 0.8631 & 0.8620
\end{tabular}

Notes: All regressions are conducted by using the Newey-West (1987) heteroskedasticity and autocorrelation consistent covariance matrix. Reg. means regression, Const. means constant term, and $\operatorname{Adj} . R^{2}$ denotes the adjusted $R$-squared value. Further, $* * *, * *, *$ attached to the coefficients denote their statistical significance at the $1 \%, 5 \%$, and $10 \%$ levels, respectively. 
Table 3. Results of Regressions on Debt Ratios as to the Japanese Electrical-related Industry Firms: Determinants of Leverage for the Fiscal Year from 1981 to 2012

Panel A. Panasonic

\begin{tabular}{|c|c|c|c|c|c|}
\hline & Reg. 1 & Reg. 2 & Reg. 3 & Reg. 4 & Reg. 5 \\
\hline Const. & $61.8245^{* * *}$ & $64.3738 * * *$ & $49.3044 * *$ & $40.2518 * * *$ & $28.8691 * * *$ \\
\hline EBITDA & $-1.2610 * * *$ & & & & \\
\hline MB & & $-11.0446^{* *}$ & & & \\
\hline DIV & & & 1.1708 & & \\
\hline $\mathrm{RD}$ & & & & 1.7166 & \\
\hline PPE & & & & & $1.2314^{* *}$ \\
\hline \multirow[t]{2}{*}{$\operatorname{Adj} . R^{2}$} & 0.3120 & 0.1712 & -0.0302 & 0.0361 & 0.3456 \\
\hline & Reg. 6 & Reg. 7 & & & Reg. 9 \\
\hline Const. & $67.8863 * * *$ & $42.5902 * * *$ & & $* * *$ & $49.3189 * * *$ \\
\hline EBITDA & $-1.0395^{* * *}$ & $-0.8267 * * *$ & & & -0.7037 \\
\hline MB & $-6.3850 *$ & & & & -2.6566 \\
\hline DIV & & & & & -2.3485 \\
\hline $\mathrm{RD}$ & & & & & $-1.9930^{*}$ \\
\hline PPE & & 0.8745 & & & $1.4213 *$ \\
\hline $\operatorname{Adj} . R^{2}$ & 0.3475 & 0.4433 & & & 0.4853 \\
\hline
\end{tabular}

Panel B. Sony

\begin{tabular}{|c|c|c|c|c|c|c|}
\hline & Reg. 1 & Reg. 2 & Reg. 3 & Reg. 4 & Reg. 5 & Reg. 6 \\
\hline Const. & $80.2139 * * *$ & $70.1571 * * *$ & $80.0384 * * *$ & $88.7713 * * *$ & $80.5446^{* * *}$ & $82.7423 * * *$ \\
\hline EBITDA & $-1.3442 * * *$ & & & & & $-1.1064 * * *$ \\
\hline MB & & -0.6103 & & & & \\
\hline DIV & & & $-8.5544 * * *$ & & & -3.5016 \\
\hline $\mathrm{RD}$ & & & & $-3.6844 * * *$ & & \\
\hline PPE & & & & & $-0.6046^{* * *}$ & \\
\hline \multirow[t]{2}{*}{$\operatorname{Adj} . R^{2}$} & 0.5613 & -0.0242 & 0.3244 & 0.5844 & 0.3635 & 0.5886 \\
\hline & Reg. 7 & Reg. 8 & Reg. 9 & Reg. 10 & Reg. 11 & Reg. 12 \\
\hline Const. & $89.4520 * * *$ & $81.4196^{* * *}$ & $89.2904 * * *$ & $83.6429 * * *$ & $89.5780 * * *$ & $88.3747 * * *$ \\
\hline EBITDA & $-0.8642 * * *$ & $-1.1501 * * *$ & & & & $-0.9964 * * *$ \\
\hline MB & & & & & & 0.7386 \\
\hline DIV & & & -2.5984 & -5.2029 & & 0.9304 \\
\hline $\mathrm{RD}$ & $-2.4692 * * *$ & & $-3.1570 * * *$ & & $-2.9853 * * *$ & $-2.7513 * * *$ \\
\hline PPE & & -0.1481 & & $-0.4156^{*}$ & -0.2390 & 0.0589 \\
\hline $\operatorname{Adj} . R^{2}$ & 0.7548 & 0.5575 & 0.5907 & 0.4380 & 0.6108 & 0.7437 \\
\hline
\end{tabular}

Notes: All regressions are conducted by using the Newey-West (1987) heteroskedasticity and autocorrelation consistent covariance matrix. Reg. means regression, Const. means constant term, and $\operatorname{Adj} . R^{2}$ denotes the adjusted $R$-squared value. Further, ${ }^{* * *}, * *, *$ attached to the coefficients denote their statistical significance at the $1 \%, 5 \%$, and $10 \%$ levels, respectively. 
Panel A. Apple-RD

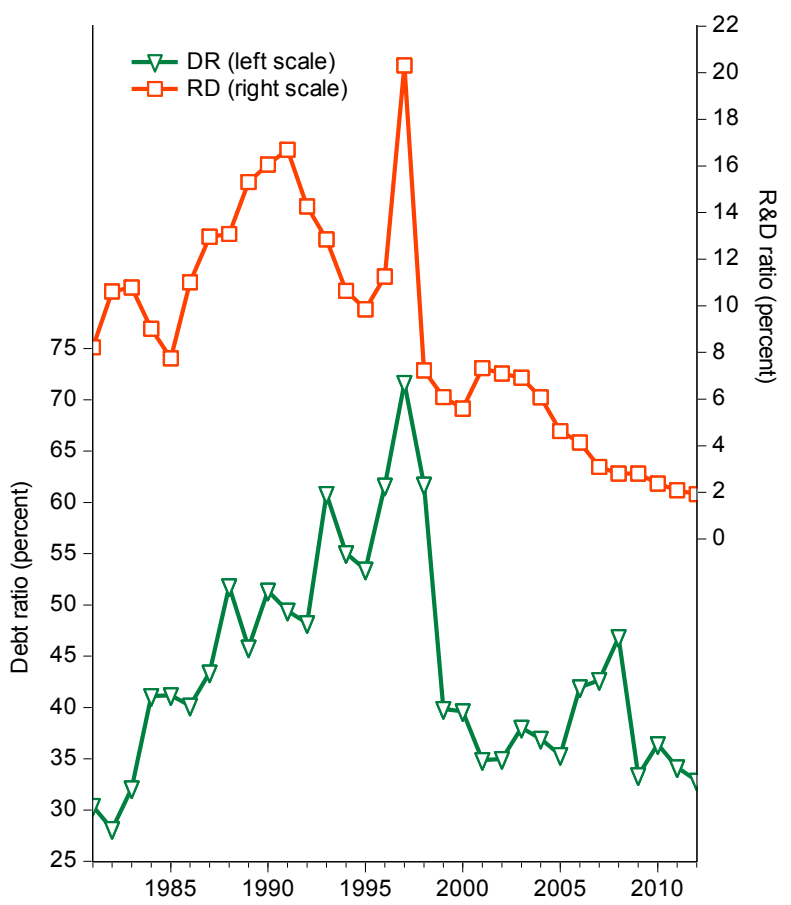

Panel C. Panasonic-EBITDA

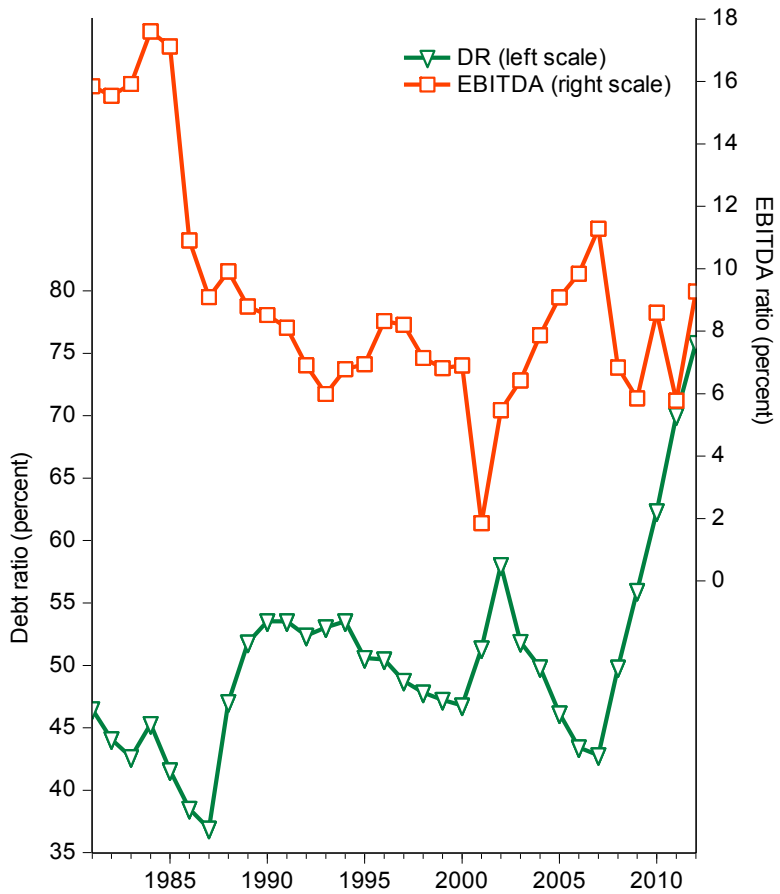

Panel B. IBM-PPE

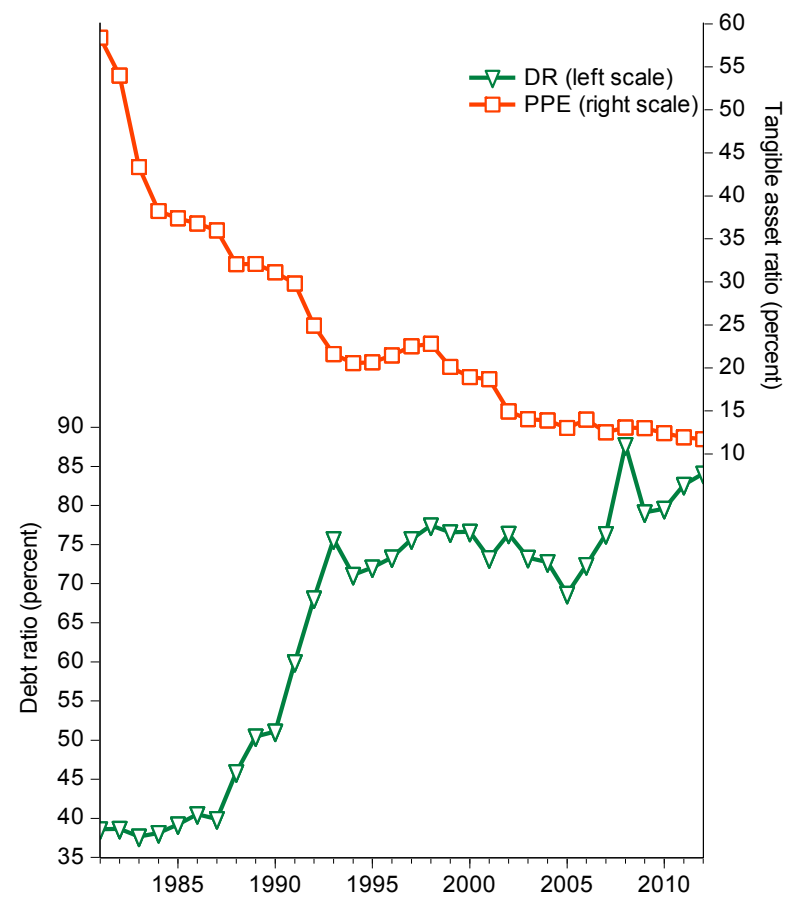

Panel D. Sony-RD

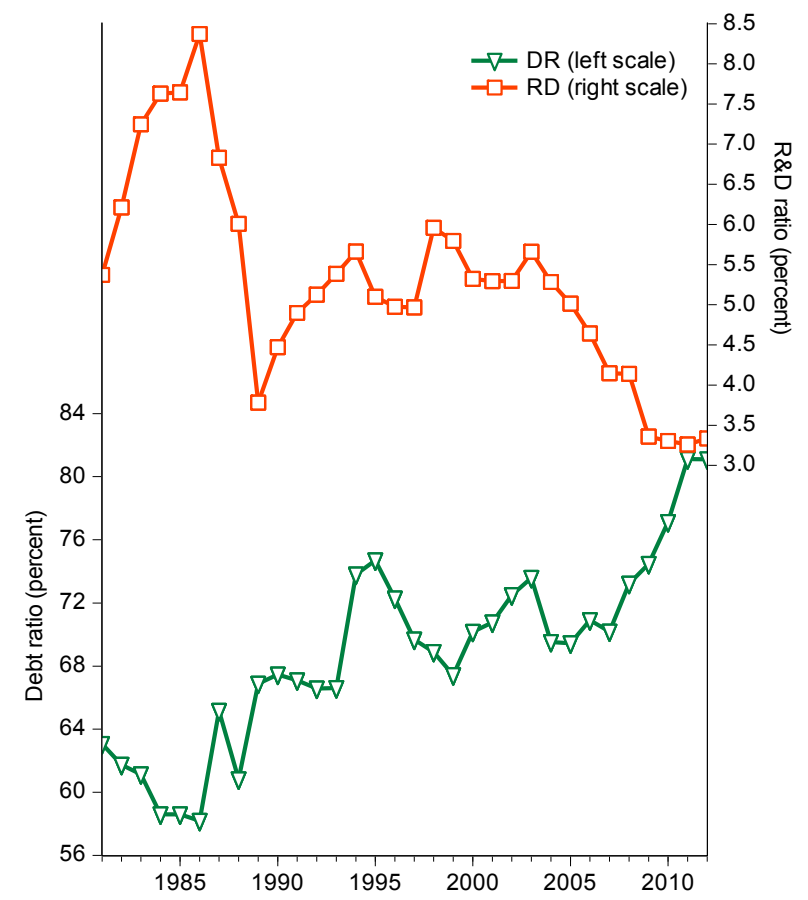

Figure 2. Debt Ratios and Their Strong Determinants in the Major US and Japanese Electrical-related Industry Firms: Time-series Trends from 1981 to 2012 


\subsection{Results for the Capital Structure Determinants}

This subsection describes the empirical results of the capital structure determinants of two US electrical-related industry firms shown in Table 2, and those of two Japanese same industry firms shown in Table 3. All results are derived from the combination regressions of the variables in equation (1), where explanatory variables are EBITDA, MB, DIV, RD, and PPE.

First, as to Apple, from Panel A of Table 2, we understand that the statistically significant determinants of the firm's debt ratio are DIV, RD, and PPE. More concretely, it is understood that in the case of Apple, the strongest explanatory variable is $\mathrm{RD}$ because the highest adjusted- $R$ squared value of 0.3948 in regression 4 can be seen and in regressions 6 and 8 , RD dominates both DIV and PPE. In connection with these results, we present the time-series dynamics of RD and the debt ratio of Apple in Panel A of Figure 2. This figure clearly shows the positive time-series linkage between two variables and this relation can be interpreted that Apple finances the R\&D expenses mainly by debt. Second, with regard to IBM, Panel B of Table 2 indicates that the statistically significant determinants of the firm's debt ratio are EBITDA, MB, RD, and PPE. More specifically, it is understood that in the case of IBM, the strongest explanatory variable is PPE since the highest adjusted- $R$ squared value of 0.8136 in regression 5 can be seen and in regressions 8, 10, and 11, PPE is always statistically significant. In connection with these results, we also exhibit the time-series dynamics of PPE and the debt ratio of IBM in Panel B of Figure 2. This figure clearly indicates the negative linkage between two variables. We interpret that the negative linkage, namely, the dynamics of the increasing leverage and decreasing PPE are seen because the historical average of PPE is high for IBM as recognized in Table 1, IBM continuously decreases PPE for improving their asset utilization efficiency whilst the firm's leverage gradually increases.

Third, regarding Panasonic, from Panel A of Table 3, we understand that the statistically significant determinants of the debt ratio of Panasonic are EBITDA, MB, and PPE. More concretely, it is understood that in the case of Panasonic, the strong explanatory variables are EBITDA and PPE. This is because the highest adjusted- $R$ squared value of 0.3456 in regression 5 can be seen whilst in regression 7, EBITDA dominates PPE. Based on the result in regression 7, we present the time-series dynamics of EBITDA and the debt ratio of Panasonic in Panel C of Figure 2. This figure clearly exhibits the negative time-series linkage between them, thus we understand that in Panasonic, when its profitability is low, the firm's debt ratio rises. Finally, as for Sony, from Panel B of Table 3, it is understood that the statistically significant determinants of the debt ratio are EBITDA, DIV, RD, and PPE. More concretely, we understand from this Panel that in the case of Sony, the strongest explanatory variable is $\mathrm{RD}$; this is because the highest adjusted- $R$ squared value of 0.5844 in regression 4 can be seen and in regressions 7, 9, and 11, RD always demonstrates the statistically significance. Based on these results, we also display the time-series dynamics of RD and the debt ratio of Sony in Panel D of Figure 2. This figure implies the negative time-series linkage between two variables; this would mean that in Sony, debt ratio continuously rises whilst it is difficult to keep its $R \& D$ expenses in the similar level. 
Table 4. Results of Regressions on Shareholders' Equity Changes: The Cases of the US and Japanese Electrical-related Industry Firms for the Fiscal Year from 1981 to 2012

\begin{tabular}{|c|c|c|c|c|c|c|}
\hline \multicolumn{7}{|c|}{ Panel A. The Cases of the Major US Electrical-related Industry Firms } \\
\hline & Apple & & & IBM & & \\
\hline Const. & 1.9751 & $72.7661 * * *$ & $45.7167 * * *$ & -2.7383 & -4.3386 & $-34.7433 *$ \\
\hline MB & $6.7297 * * *$ & & & 1.0805 & & \\
\hline PPE & & $-4.9406 * *$ & & & 0.2596 & \\
\hline $\mathrm{RD}$ & & & $-2.1373 * * *$ & & & $6.6222 *$ \\
\hline $\operatorname{Adj} . R^{2}$ & 0.2363 & 0.1592 & 0.1102 & -0.0094 & -0.0078 & 0.0312 \\
\hline \multicolumn{7}{|c|}{ Panel B. The Cases of the Major Japanese Electrical-related Industry Firms } \\
\hline & Panasonic & & & Sony & & \\
\hline Const. & -3.1581 & $54.8678 * * *$ & $34.6887 * *$ & 11.2515 & -10.0246 & $-32.0308 * * *$ \\
\hline MB & 6.0532 & & & -1.0179 & & \\
\hline PPE & & $-2.8782 * * *$ & & & $1.0175^{* *}$ & \\
\hline $\mathrm{RD}$ & & & $-5.0965^{*}$ & & & $7.7234 * * *$ \\
\hline $\operatorname{Adj} . R^{2}$ & -0.0226 & 0.3632 & 0.0847 & -0.0301 & 0.1373 & 0.3799 \\
\hline
\end{tabular}

Notes: All regressions are conducted by using the Newey-West (1987) heteroskedasticity and autocorrelation consistent covariance matrix. Reg. means regression, Const. means constant term, and Adj. $R^{2}$ denotes the adjusted $R$-squared value. Further, $* * *, * *, *$ attached to the coefficients denote their statistical significance at the $1 \%, 5 \%$, and $10 \%$ levels, respectively.

\subsection{Results for Equity Financing}

Next, we argue the results for the equity financing behavior of the four firms. The results are shown in Table 4. First, as for Apple, MB, PPE, and RD are statistically significant in Panel A of Table 4. In particular, coefficient of MB is statistically significantly positive, thus Apple raises funds by equity when its market value is high. Further, PPE and RD are negatively related with the equity increase of Apple in Table 4; on the other hand, in Table 2, the relation between PPE and debt ratio and that between RD and debt ratio are positive. Hence Apple is considered to finance the funds for R\&D and tangible assets mainly by debt rather than equity. Second, regarding IBM, only RD is weakly statistically significant with positive sign in Panel A of Table 4. On the other hand, in Table 2, the relation between RD and debt ratio of IBM is statistically significantly negative. Hence IBM seems to finance the funds for R\&D mainly by equity rather than debt.

Further, as for Panasonic, RD and PPE are statistically significant with negative sign in Panel $\mathrm{B}$ of Table 4. On the other hand, in Table 3, the relation between RD and debt ratio and that between PPE and debt ratio are positive for Panasonic (Only PPE is statistically significant). Hence Panasonic is considered to finance the funds for property, plant, and equipment mainly by debt rather than equity. Finally, with regard to Sony, RD and PPE are statistically significant with positive sign in Panel B of Table 4. Contrary to this, in Table 3, the relation between RD and debt ratio and that between PPE and debt ratio of Sony are both statistically significantly negative. Hence based on these results, Sony is considered to finance the funds for property, plant, and equipment and $R \& D$ expenses by mainly using equity rather than debt. 


\section{Summary and Conclusions}

This paper explored the corporate financing behavior of the four famed electrical-related industry firms in the US and Japan. It is interesting for analyzing financing policies of different firms that are in different corporate life cycles and in different economic environment; the four firms explored in this case study have also different management styles. More specifically, Apple is one of the rapidly growing firms; IBM is a well-established firm which has long successful stories and is matured and stable; Panasonic is also a well-established firm but suffering from the Japanese long hard economic condition; Sony is a well-known challenging firm that invited the executive officer from the US but has been facing the difficulty in recovering corporate profitability. As above, it is meaningful to select and analyze the different characteristic firms in almost the same industries in detail by case studies as our present study.

The interesting findings from our case studies can be summarized as follows. (1) First, as for Apple, its market valuation is related to its equity financing behavior, and Apple is considered to finance the funds for R\&D and tangible assets mainly by debt rather than equity. However, the company decreased its debt ratio after around 1998, and it is noted that the capital structure of the firm changed to low leverage structure in the recent period. (2) Second, regarding IBM, the company is considered to finance the funds for R\&D mainly by equity rather than debt; however, their debt ratio is generally high. Further, the company's profitability and payout levels are also high, and the firm increased its asset utilization efficiency by continuously decreasing the tangible asset to total asset ratio. (3) Third, as for Panasonic, the firm is considered to finance the funds for property, plant, and equipment mainly by debt rather than equity, and recently, its debt ratio rapidly increased. (4) Finally, as to Sony, the company is considered to finance the funds for property, plant, and equipment and $R \& D$ expenses mainly by equity rather than debt; however, its level of debt ratio is also generally high. In addition, profitability of the above two Japanese firms is generally lower than two US firms analyzed in this paper; it is expected to improve their profitability under the recent recovering Japanese economic conditions.

As above, different firms have rather different corporate capital structure, corporate financial conditions, and corporate financing behavior. We consider that specific case studies like ours are quite useful for recognizing the differences of corporate financial characteristics and fund raising behavior directly. It is noted that this paper does not aim to derive the common results but aim to clarify the differences of corporate financing behavior of the four firms that have different characteristics in various aspects. However, unlike the analyzing style and objective of our present study, as another future research, more rigorous quantitative comparison by carefully choosing larger sample seems to be also significantly effective to clarify the common and major corporate financing policies and behavior, thus this line of research is also one of my future works.

\section{Acknowledgement}

I am particularly grateful to the kind repeated invitation from the journal to write to this journal. Further, I greatly thank the Editor and anonymous reviewers for their kind comments 
to this paper. I also appreciate the Japan society for the promotion of science and the Chuo university grant for special research for their generous financial assistance to this research.

\section{References}

Baker, M., \& Wurgler, J. (2002). Market timing and capital structure. Journal of Finance, 57, 1-32. http://dx.doi.org/10.1111/1540-6261.00414

Bonaimé, A. A., Öztekin, Ö., \& Warr, R. S. (2014). Capital structure, equity mispricing, and stock repurchases. Journal of Corporate Finance, 26, 182-200. http://dx.doi.org/10.1016/j.jcorpfin.2014.03.007

Chang, Y. K., Chou, R. K., \& Huang, T. H. (2014). Corporate governance and the dynamics of capital structure: New evidence. Journal of Banking \& Finance, forthcoming. http://dx.doi.org/10.1016/j.jbankfin.2014.04.026

Chung, Y. P., Na, H. S., \& Smith, R. (2013). How important is capital structure policy to firm survival? Journal of Corporate Finance, 22, 83-103. http://dx.doi.org/10.1016/j.jcorpfin.2013.04.002

Danis, A., Rettl, D. A., \& Whited, T. M. (2014). Refinancing, profitability, and capital structure. Journal of Financial Economics, forthcoming. http://dx.doi.org/ 10.1016/j.jfineco.2014.07.010

Frank, M. Z., \& Goyal, V. K. (2009). Capital structure decisions: Which factors are reliably important? $\quad$ Financial Management, $\quad 38, \quad$ 1-37. http://dx.doi.org/10.1111/j.1755-053X.2009.01026.x

Myers, S. C., \& Majluf, N. S. (1984). Corporate financing and investment decisions when firms have information that investors do not have. Journal of Financial Economics, 13, 187-221. http://dx.doi.org/10.1016/0304-405X(84)90023-0

Newey, W. K., \& West, K. D. (1987). A simple, positive semi-definite, heteroskedasticity and autocorrelation consistent covariance matrix. Econometrica, 55, 703-708. http://dx.doi.org/10.2307/1913610

Vermaelen, T., \& Xu, M. (2014). Acquisition finance and market timing. Journal of Corporate Finance, 25, 73-91. http://dx.doi.org/10.1016/j.jcorpfin.2013.11.004

Yang, B. (2013). Dynamic capital structure with heterogeneous beliefs and market timing. Journal of Corporate Finance, 22, 254-277. http://dx.doi.org/10.1016/j.jcorpfin.2013.05.003

\section{Copyright Disclaimer}

Copyright for this article is retained by the author(s), with first publication rights granted to the journal.

This is an open-access article distributed under the terms and conditions of the Creative Commons Attribution license (http://creativecommons.org/licenses/by/3.0/). 